\title{
Will austerity cuts dismantle the Spanish healthcare system?
}

In the face of austerity, a series of disconnected "reforms" could, without corrective measures, lead to the effective dismantling of large parts of the Spanish healthcare system, with potentially detrimental effects on health. Helena Legido-Quigley and colleagues explain

\author{
Helena Legido-Quigley lecturer ${ }^{1}$, Laura Otero associate lecturer ${ }^{2}$, Daniel la Parra senior lecturer ${ }^{3}$, \\ Carlos Alvarez-Dardet professor of public health ${ }^{4}$, Jose M Martin-Moreno professor of preventive \\ medicine and public health ${ }^{5}$, Martin McKee professor of European public health ${ }^{1}$
}

${ }^{1}$ London School of Hygiene and Tropical Medicine, UK; ${ }^{2}$ Faculty of Nursing, University of Lleida, Spain; ${ }^{3}$ Department of Sociology II, University of Alicante, Spain; ${ }^{4}$ CIBER en Epidemiología y Salud Pública (CIBERESP), University of Alicante, Spain; ${ }^{5}$ Department of Preventive Medicine and Public Health and Clinical University Hospital, University of Valencia, Spain

The financial crisis has hit Spain hard. Initially, given its low government debt, Spain seemed safe, but it was forced to bail out its banks when the housing boom they had been fuelling finally collapsed. ${ }^{1}$ In the first quarter of $2013,27 \%$ of the labour force were unemployed, ${ }^{2}$ including over $57 \%$ of the under $25 \mathrm{~s}$. Poverty has increased. Twenty one per cent of the Spanish population lived below the poverty line in 2012 , on less than $€ 7354$ (£5980; \$9599) annually. ${ }^{3}$

In June 2012 the Spanish government negotiated a $€ 100 \mathrm{bn}$ intervention with the European Stability Mechanism (ESM) to support the banks. In 2012, the general government deficit reached $8.1 \%$ of GDP, ${ }^{4}$ against a target of $5.3 \%$, and its debt rose from $26.7 \%$ of GDP in 2007 to $93.8 \%$ in $2012 .{ }^{5}$

\section{The system}

Public expenditure on healthcare is low. Although, in 2010, Spain spent $9.6 \%$ of GDP on healthcare, $26 \%$ of this was from private sources (6\% private insurance and the remaining $20 \%$ paid by individuals) and $74 \%$ was public, with the latter equivalent to $7.0 \%$ of GDP, compared to an average of $7.6 \%$ in the European Union. ${ }^{6}$ Yet the Spanish health system is viewed positively by the public. In a 2011 national survey $73.1 \%$ of 7800 individuals said that the Spanish system was working fairly well or well. ${ }^{7}$ Professional dissatisfaction (attributed to low salaries), procurement problems, and limited access to some specialties were issues before the crisis. However, the Spanish system performed better than neighbouring countries. ${ }^{8}$

The national health ministry is responsible for the equitable functioning of the system, pharmaceutical legislation, border health issues, and international health relations. All other issues are devolved to the 17 regions, which administer $90 \%$ of public healthcare funding. ${ }^{9}$ Following budgetary shortfalls in some regions in 2012 , the central government created an $€ 18$ bn regional liquidity fund to ensure their financial sustainability, ${ }^{10}$ with a further $€ 23 b n$ in 2013.

\section{The cuts}

\section{The national situation}

The health and social services budget was reduced by $13.65 \%$ in 2012, with disproportionately high cuts to professional training $(75 \%)$ and public health and quality programmes (45\%). ${ }^{112}$ These cuts coincided with increased demands on the health system, in part reflecting the association between unemployment and poor mental health, but also because of a cut of $€ 600 \mathrm{~m}$ in the dependency fund that supports elderly people and people with disabilities. ${ }^{11}$

These budgetary changes were accompanied by a structural change that was introduced, unusually, not after parliamentary debate, but by a royal decree. ${ }^{13}$ Royal Decree-law (Real Decreto-ley) 16/2012 came into force in September 2012, excluding undocumented migrants from all but basic emergency care, prenatal care, and paediatric care, so ending the principle of free services at the point of delivery for all.

There have been changes in copayments for drugs. Pensioners now have to pay: those on higher incomes will pay $10 \%$ of the cost of medicines, and others will pay between $€ 8$ and $€ 60$ per month depending on their pension. Those in employment will pay up to $60 \%$ more for their medicines, depending on their income, with those earning less than $€ 18000$ annually paying $40 \%$ of the cost of medicines. Copayments have been extended to prosthetics, dietary products, and non-urgent ambulance trips-people with disabilities will pay $€ 5$ for ambulance trips. ${ }^{14}$ 
Drug purchasing will be centralised. ${ }^{11}$ A national working group is reviewing the list of reimbursed goods and services that the regions provide and is expected to recommend further cuts. ${ }^{15}$

Finally, the national government has anounced a further $€ 3134 \mathrm{~m}$ cut for $2013,{ }^{16}$ including an additional $€ 1108 \mathrm{~m}$ to be taken from the dependency fund for elderly people and people with disabilities, of which $€ 571 \mathrm{~m}$ will come from the regions. ${ }^{11}$

\section{The regional situation}

Some regions have resisted the centrally imposed austerity, seeking ways to protect migrants and others left without cover. Other regions, such as Madrid and Catalonia, have gone further (see box 1 in the online version for details). They had already cut budgets by $10 \%$ and $7 \%$ respectively in 2011; both also proposed fees of $€ 1$ for each prescription. Both have also made it easier for private companies to run hospitals, which is widely seen as a measure hobbled by conflicts of interest that threaten equitable service provision, rather than one based on evidence of efficiency savings. This perception is supported by the low cost and relative efficiency of the public system as compared to other European countries. The budgetary cuts have been associated with an increase in numbers on waiting lists between 2010 and 2011, by $43 \%$ in Catalonia, leading to increasing delays in obtaining treatment. Surgical procedures fell by over $15 \%$ in the same period. ${ }^{16}$ There have been cutbacks in emergency services in several regions. In the Valencian Autonomous Community and Castilla-La Mancha pharmacists have gone on strike, protesting against the regional governments' inability or unwillingness to reimburse them for drugs dispensed.

\section{Demonstrations against austerity}

Both the Spanish Socialist Workers' Party (Partido Socialista Obrero Español) and, following its election in November 2011, the People's Party (Partido Popular), introduced a series of austerity packages including cuts to public sector employee salaries; cuts to budgets for education, science, health, and social services; more restrictive labour laws; and higher taxation, with value added tax rising from $16 \%$ in 2010 to $21 \%$ in 2012 .

These measures have generated widespread popular discontent. Demonstrations on 15 May 2011 led to the emergence of the 15-M Movement (Movimiento 15-M). Known as the Indignants these protestors complained that the traditional parties failed to represent the views of citizens, offered no solutions to the crisis, and had failed to curb the excesses of the banks and corporations. The Indignants, together with other social movements, tapped into a newly awakened popular consciousness, and mounted demonstrations to defend the public healthcare system (the so called Marea Blanca, or White Tide), and occupied health facilities. Some now consider that they are witnessing the dismantling of the Spanish healthcare system.

\section{Impact and reaction to the cuts}

There has been little research on the impact on the cuts on health. A study comparing patients attending primary care centres in 2006-07 ( $\mathrm{n}=7940)$, and after the crisis, in 2010-11 $(n=5876)$, found large and statistically significant increases in the proportion of patients reporting depression (19.4 percentage points) and other mental disorders, including anxiety and alcohol related disorders. Individual or family unemployment accounted for $23 \%$ of the population attributable risk of attending with major depression in 2010-11, and mortgage arrears added a further $11 \% .{ }^{17} \mathrm{~A}$ cross sectional survey of almost 20000 people, reached similar conclusions, with a $17.5 \%$ increase in symptoms of depression in the adult population between the two survey points of 2006 and 2010. ${ }^{18}$ Police report a $10 \%$ increase in suicides in Catalonia between 2010 and 2011, from 492 to 541, and a $20 \%$ increase in unsuccessful attempts, from 1953 to 2379. ${ }^{19}$

We undertook 34 qualitative interviews on a convenience sample of doctors and nurses in 18 hospitals and 16 primary healthcare facilities in Catalonia in early 2012 (see box 2 in the online version for methodology and relevant quotes). Although the interviewees cannot be considered as representative, their views seemed consistent with public opinion surveys.

Sampling approximately 2500 adults aged 18 and over in each wave, successive national barometer surveys consistently report the healthcare system as functioning properly with no need for reforms (nearly $24.2 \%$ ). Nearly $50 \%$ thought that it works well but some changes are needed. A majority of Spaniards support increased healthcare expenditure in primary health care settings $(87 \%)$, which suggests a rejection to the introduced cuts. ${ }^{20}$ When asked to pick from a list the greatest challenges Spain faces, unemployment came first, at $77 \%$, the economic crisis second at nearly $40 \%$, and politicians third, at $30 \%$. Importantly, fourth position is occupied by corruption and fraud, at $17 \%$. The healthcare system trailed in fifth position at $13 \%$, but increased 4 percentage points between September 2012 and December 2012, the period coinciding with the most recent healthcare reforms. ${ }^{21} 22$

The concern among our interviewees about alleged corruption and conflicts of interest is also borne out by media reports, often involving a perceived revolving door between public employees and private companies. Recent prominent examples in Catalonia, ${ }^{23}$ Madrid, ${ }^{24}$ and Valencia, ${ }^{24}$ have fuelled speculation that some decisions about healthcare reform conceal an intention to divert resources to the private sector. ${ }^{25} 26$

\section{Changes that alter the principles of Spanish healthcare}

The exclusion of undocumented immigrants, increasing copayments, and privatisation of services are the three most important changes.

The royal decree prevents around 500000 undocumented migrants ${ }^{27}$ over the age of 18 accessing the full range of healthcare in Spain. Since its announcement the government has said that primary care services will be available to those under 65 years who pay a monthly fee of $€ 59.20$ and up to $€ 155.40$ for those over 65 years. ${ }^{28}$ Such payments may prove unaffordable and are more expensive than existing private policies in Spain-perhaps raising suspicions in some that the policy is designed to favour the private sector. The situation is fluid: in December 2012, the Spanish Constitutional Court upheld the right of the Basque Country to provide free services to undocumented immigrants. The court prioritised health over finances and noted that the central government had not shown how its policy would result in any savings. It is expected that the central government will appeal.

Some regions (Catalonia, Andalusia, Asturias, Canary Islands, and the Basque Country) have refused to exclude undocumented immigrants, arguing that it is unjust, dangerous, and potentially unconstitutional. Professionals and organisations have also expressed concern about their ethical duty to provide care to undocumented migrants. The Spanish Society of Family and Community Physicians (Sociedad Española de Medicina de Familia y Comunitaria or semFYC) refused to withdraw treatment. Amnesty International and Doctors of the World have 


\begin{abstract}
Box 1: Healthcare reforms and cuts in Catalonia and Madrid
Catalonia

In 2011, the Catalan nationalist party Convergence and Union (Convergència $i$ Unió) reduced the healthcare budget by $10 \%{ }^{48}$ and made a further reduction of nearly $5 \%$ in $2012,{ }^{49}$ with per capita expenditure decreasing from $€ 1292$ in 2011 to $€ 1128$ in $2012 .{ }^{50}$ Press reports suggest that the government is planning a further $15 \%$ cut for $2013,{ }^{51}$ although this figure is yet to be confirmed.

Healthcare professionals have had a $5 \%$ wage cut imposed by the national government in 2010 with an additional $3 \%$ cut imposed by the Catalan government in 2011.

Since then about a third of hospital beds and operating theatres have closed, emergency care has been reduced at night in many primary care centres, services have been closed down in the afternoon, and operations for certain conditions have been cancelled..$^{48}$

One of the most controversial measures adopted by the Catalan government is the $€ 1$ prescription fee, with upper limits for those using large quantities of medicine, and exclusions for pensioners and people on low incomes. This measure has subsequently been suspended by the Spanish Constitutional Court.

There have already been prominent cases where deaths of patients have been attributed to cuts. These cases included a patient transferred among a series of hospitals because none could provide the necessary surgery, finally to die in the fourth hospital, and another who died from a brain haemorrhage after four days in the emergency department of a specialist hospital (Hospital Universitari Vall d'Hebron) withou receiving an MRI. This case is currently being investigated by the judicial authorities to determine if the delay played a role in the death.

A coalition of community groups and NGOs in Catalonia has initiated criminal proceedings against the Catalan minister of health, alleging failure to provide assistance in emergencies, and conflict of interest. A number of health facilities facing privatisation have been occupied by protestors. In addition, the Catalan parliament has initiated a commission to investigate the management of the Catalan healthcare system, although the two major political parties Convergència i Unió and the Catalan Socialist Party, have vetoed some hearings regarding alleged corruption. ${ }^{52}$

Madrid

The government of Madrid is planning to reduce its healthcare budget by $7 \%$. It will privatise six recently built hospitals (Infanta Leonor Hospital, Infanta Sofía Hospital, Infanta Cristina Hospital, Del Henares Hospital, Del Sureste Hospital, and Tajo Hospital), partially privatise the remaining hospitals by outsourcing non-health services, privatise $10 \%$ of the primary healthcare centres, close the Institute of Cardiology, and centralise laboratory services. It will also privatise the Central Laundry for Hospitals and the Central Unit of Radiology. As in Catalonia, a proposed $€ 1$ prescription fee has been suspended by the Constitutional Court. Healthcare professionals opposed to these reforms have initiated demonstrations and an unprecedented strike of indefinite duration. ${ }^{53}$ In Madrid 322 healthcare managers have resigned because privatisation is going ahead. Resignations will affect 137 primary healthcare centres; the whole team resigned in 90 centres.
\end{abstract}

drawn attention to the consequences of withdrawing treatment for HIV and tuberculosis, as well as the risks of drug resistance and spread of disease. ${ }^{29}$

Concerns have been expressed about the copayments ${ }^{30}$; the available evidence indicates that they are largely ineffective in containing costs ${ }^{31}$ and may cost more to collect than they raise. The RAND Health Insurance Experiment, a large randomised controlled trial, found that copayments deter necessary and unnecessary care to the same extent. ${ }^{32} 33$

There is a similar lack of evidence to support the privatisation of facilities being pursued in some regions such as Catalonia and Madrid. Claims of the superiority of private sector provision have not been supported by systematic reviews in low and middle income countries ${ }^{34} 35$ or by a range of studies in high income countries. A meta-analysis of 31 studies of ownership of US hospitals found no consistent difference once methodological and sampling differences were accounted for. ${ }^{36}$ Similar findings were reported in a review of studies of efficiency in German hospitals. ${ }^{37}$ Other research has described differences in characteristics and outcomes of public and private healthcare. Lower staffing and efficiency was found in private hospitals in Greece. ${ }^{38}$ Research comparing Italian regions found slower reductions in mortality in regions with greater private hospital provision. ${ }^{39}$ The UK's private finance initiative (PFI) scheme, and similar schemes in countries such as Australia and Spain, have identified major problems with this form of procurement. $^{40}$

\section{The alternatives}

Some commentators have called for savings from other sources, such as a clampdown on tax evasion and on other forms of fraud, which are estimated to account for $€ 80 \mathrm{bn}$ per year-approximately equal to the total cost of the health system. ${ }^{4142} 43$ These observations have led some to ask whether the Spanish health model, which is inexpensive and highly regarded by those who use it, is being changed not because of any particular need to reform it (beyond that of responding incrementally to the challenges faced by all health systems) but rather because of a determination to reduce the size of the state. Internationally, there is a growing recognition that the policies of austerity being pursued by some European governments are making the economic situation worse. ${ }^{44}$ This failure of austerity policies is exemplified by a recent reassessment by the International Monetary Fund of the consequences of cuts for economic growth, ${ }^{45}$ coupled with moves to create a Europe-wide regulatory system for banks which, had it been in place, would have prevented many of Spain's current economic woes.

There are still those who see crises as an opportunity to pursue their ideological goals of dismantling the European welfare state, as foreseen by the Canadian author Naomi Klein. ${ }^{46}$ On the other hand, there is also a rising chorus of alternative voices, from all parts of the political spectrum and civil society, arguing that different economic policies should be pursued. In addition, there is increasing evidence, ${ }^{47}$ often unwelcome to the governments concerned, of the human consequences of their policies.

Contributors: $\mathrm{HL}-\mathrm{Q}$ and $\mathrm{MM}$ drafted the article. All authors revised subsequent drafts. HL-Q conducted the interviews in Catalonia. HL-Q is guarantor.

Competing interests: All authors have read and understood the BMJ Group policy on declaration of interests and declare the following interests: none.

Ethical approval: The research was approved by the Ethics Committee of the London School of Hygiene and Tropical Medicine. All participants were informed about the content of the study and its likely outcomes and were informed of their right to refuse to answer any question that they did not wish to answer. A consent form provided information on the research, including the confidentiality and anonymity of interviewees' responses. All participants read the information sheet, signed the consent form, and gave written consent to their interview data being included in publications.

Provenance and peer review: Not commissioned; externally peer reviewed. 


\section{Box 2: Healthcare professionals in Catalonia: experiences and opinions on the cuts \\ Methodology}

A total of 34 interviews were conducted with healthcare professionals (30 doctors and 4 nurses), in hospitals (18) and in primary care (16) in both the public and private sector. Settings spanned urban and rural areas around Barcelona and Girona. Interviewees comprised trainees, consultants, and heads of services both in short term and permanent positions. Interviews lasted approximately 90 minutes with the shortes being 30 minutes and the longest 3 hours. Interviews were conducted in Catalan and Spanish and were all recorded. Participants were asked about their day job before and after the reforms were introduced; their experience of the healthcare reforms; their views on the changes; and their opinion about future solutions. Interviews were coded deductively, following a thematic analysis. Ethical approval was obtained from the London School of Hygiene and Tropical Medicine.

Some interviewees reported not having been consulted and being shocked, numbed, and disillusioned. A consultant, working for the private sector, considered that the cuts were necessary and appropriate. Several interviewees offered examples of how patients were being adversely affected. Some reported that they were finding ways to cope, although they were not clear how long this could last. There was a perceived lack of clarity about both the ultimate direction of the changes and how they were impacting on population health. When asked about alternative solutions to those being proposed by the regional government, almost none felt able to make an accurate assessment of the situation because of lack of information. Their concerns were consistent with the experience of researching this paper, as there seems little official interest in assessing the impacts of the policies being implemented. Some interviewees thought that the managers and politicians were promoting increased commercialisation of the healthcare sector to serve their own interests. Some made allegations of corruption and conflicts of interest.

\section{What healthcare workers say}

\section{Impact of the cuts and personal experiences}

"From one day to the next they cut $10 \%$ of the budget, we close beds, we close operating theatres for four months, we operate at $40 \%$ of our capacity ... this is like if you have a highway of three lanes and you cut two, you will have a traffic jam. They have done it so badly "--specialist doctor in tertiary hospital

"As for my mental health I am feeling very bad, especially because we are restricted with operating theatre rooms. Two days ago I had to send a patient for an urgent cardiac surgery, and all the operating rooms were being used because the others had been closed down ... was responsible for a patient in a critical condition, and I couldn't do anything. This was very painful, and I had a horrible time. Finally I managed to transfer the patient to a private hospital, and now we will have to pay the private sector for his surgery because the public sector is closing down operating theatres ... I am not sure this is very cost effective."- hospital consultant

"The cuts are killing people. My husband has heart problems ... If I called the 061 to get an ambulance because he has had a heart attack it now puts you on hold for 45 minutes. I haven't told him that ... of course, the cuts are going to kill people."-nurse in hospital

"With the introduction of the cuts, last year they told me 'now you have to go back to your position of visiting patients rather than your technical position.' I had not seen a patient in 20 years. I think these decisions are crazy. They have done this with me to save six months on a substitution ... I am going to try my best, but I am aware that I am not competent to treat my patients properly."-general practitioner

\section{Solutions to the proposed cuts}

"Nobody listens to the professional and asks for their opinion. Our opinion is valuable, but nobody has asked us. In terms of patients, you don't really know what is happening with them [after they visited the interviewee], and I am sure this will have an impact on mortality rates."primary healthcare consultant

"You don't know where the money is coming from, and what it is being used for, or how is it managed ... how am I going to propose solutions from here? I get the feeling that we spend too much money ... you know the corruption we have in Spain, there is zero transparency ... wouldn't know what to propose."-hospital consultant

\section{The reasons behind the cuts}

"The government changes and the eleven starting to run the (Catalan) health service are from the private sector, all of them have worked in private insurance companies ... there is a clear intention to privatise and make business, and take a part of it. In this country we have only made houses, and there is potential to make money on health and social services. There are lots of interests behind this, there are loads of friends, there is a cloud ... That is why there is despair."-specialist doctor, tertiary hospital

"The Socialist Party [previous government in Catalonia governing in coalition with two other parties] was already privatising. They were all doing it, and where are all these people now? They are all now working for a private insurance company, Mutua de Terrassa. The new government is doing the cuts so ferociously that people are in shock. People think, at least I have my legs left. They have taken my table and my chair, but I still have my legs left."-nurse in hospital

1 European Commission. European Economic forecast Autumn 2012. Economic and Financial Affairs, 2013.

2 Instituto Nacional de Estadistica. Encuesta de Población Activa (EPA) Primer trimestre de 2013 (population survey, first quarter of 2013). 2013. Instituto Nacional de Estadistica, 2012.

3 Instituto Nacional de Estadistica. Encuesta de Condiciones de Vida Año 2012. Datos provisionales (Conditions of life survey, 2012, provisional data). Prensa ND, ed. Instituto Nacional de Estadistica, 2012.

4 International Monetary Fund. World Economic Outlook Data. 2012. www.econstats.com/ weo/CESP.htm.

5 OECD. Sovereign borrowing outlook 2013. OECD, 2013

6 OECD. Health at a glance: Europe 2012. OECD Publishing, 2012.

7 Gené-Badia J, Gallo P, Hernández-Quevedo C, García-Armesto S. Spanish health care cuts: Penny wise and pound foolish? Health Policy 2012;106:23-8.

8 Martin-Moreno JM, Alonso P, Claveria A, Gorgojo L, Peiró S. Spain: a decentralised health system in constant flux. BMJ 2009;338:b1170.

9 García-Armesto S, Begoña Abadía-Taira M, Durán A, Hernández-Quevedo C Bernal-Delgado E. Spain: health system review. Health Syst Transit 2010;12:1-295.

10 BOE. Real Decreto-ley 21/2012, de 13 de julio, de medidas de liquidez de las Administraciones públicas y en el ámbito financiero (Royal Decree-law 21/2012, 13th July, measures to reform public administration and the financial system). Núm. 168 Sábado 14 de julio de 2012. Boletin Oficial del Estado, 2012.

11 Spanish Government. Programa Nacional de Reformas (National Programme of Reforms). La Moncloa, 2013.

12 El Mundo, Sanidad tendrá un recorte de 7.000 millones y Educación de 3.000 (Healthcare will have cuts of 7.000 and education of 3,000), 2012,

13 BOE. Real Decreto-ley 16/2012, de 20 de abril, de medidas urgentes para garantizar la sostenibilidad del Sistema Nacional de Salud y mejorar la calidad y seguridad de sus prestaciones (Royal Decree-Law 16/2012, 20th April (Urgent measures to ensure the sustainability of the national health system and improve the quality and safety of its services). Núm. 98 Martes 24 de abril de 2012. Boletin Oficial del Estado, 2012.

14 Rincon R. Los enfermos crónicos pagarán por ir en ambulancia a sus tratamientos (Chronic patients will have to pay for the ambulance service). El Pais , 12 December 2012.
15 La Vanguardia, El Gobierno hará más recortes y ampliará el copago para ahorrar 3.134 millones en sanidad en 2013 (The government will make more cuts and extend the copayment to save 3.134 million on health in 2013), La Vanguardia , 30 April 2013

16 Balsells $\mathrm{F}$. Las listas de espera aumentan el $43 \%$ por los recortes de Mas en sanidad (Waiting times increase by $43 \%$ due to the health care cuts introduced by Mas in health care). El Pais , 2012.

17 Gili M, Roca M, Basu S, McKee M, Stuckler D. The mental health risks of economic crisis in Spain: evidence from primary care centres, 2006 and 2010. Eur J Public Health 2013;23:103-8.

18 Agència d'Informació Avaluació i Qualitat en Salut. Informe de Salut de Catalunya 2011 (Health Report Catalonia 2011), 2012. Observatori del Sistema de Salut de Catalunya, Servei Català de la Salut. Departament de Salut. Generalitat de Catalunya.

19 Gallardo A. Las muertes por suicidio crecen el $10 \%$ en Catalunya durante la crisis (Deaths due to suicide grow $10 \%$ in catalonia during the crisis). El Periodico, 23 June 2012.

20 Health Information Institute, Barometro de Salud (Health Barometer) 2011. Ministry of Health, Social Policy and Equality, 2012.

21 CIS. Barometro de Septiembre (September Barometer). Madrid, Centro de Investigaciones Sociologicas, 2012

22 CIS. Barometro de Diciembre (December Barometer). Madrid, Centro de Investigaciones Sociologicas, 2012

23 Pérez Pons M, Roger M. Dimite el presidente del ICS acosado por los escándalos en la sanidad catalana. EI Pais Tarragona/Barcelona, 29 June 2012.

24 Abril G, Seviallano E, Prats J. De la pública a la privada y al revés. EI Pais Madrid/Valencia, 2 December 2012.

25 SESPAS. Posicionamiento de SESPAS sobre las políticas de privatización de la gestión de los servicios sanitarios. 2012. www.sespas.es/adminweb/uploads/docs/Posicion.pdf.

26 Garcia-Rada A. La demolición programada de la sanidad pública. El Pais , 24 September 2012.

27 Casino G. Spanish health cuts could create "humanitarian problem." Lancet 2012;379:1777.

28 Elorza A. Sanidad exige 710 euros al año a los sin papeles por ser atendidos (The Mimistry of Health demands 710 euros to ilegal inmmigrants to be attended). EI Pais Madrid, 6 August 2012. 
29 Amnesty International, Doctors in the World, Red Acoge. Contra la reforma sanitaria que puede costar vidas (Against a health care reform that can cost lives). Comunicado de Prensa, 2012.

30 Thomson S, Foubister T, Mossialos E. Can user charges make health care more efficient? BMJ 2010;341:c3759.

31 Trivedi AN, Moloo H, Mor V. Increased ambulatory care copayments and hospitalizations among the elderly. N Engl J Med 2010;362:320-8.

32 Newhouse J, Insurance Experiment Group. Free for all? Lessons from the RAND health insurance experiment. Harvard University Press, 1993.

33 Gemmill MC, Thomson S, Mossialos E. What impact do prescription drug charges have on efficiency and equity? Evidence from high-income countries. Int $J$ Equity Health 2008;7:12.

34 Basu S, Andrews J, Kishore S, Panjabi R, Stuckler D. Comparative performance of private and public healthcare systems in low- and middle-income countries: a systematic review. PLOS Med 2012;9:e1001244.

35 Montagu DD, Anglemyer A, Tiwari M, Drasser K, Rutherford GW, Horvath T, et al. Private versus public strategies for health service provision for improving health outcomes in resource-limited settings. Global Health Sciences, University of California, 2011.

36 Eggleston K, Shen YC, Lau J, Schmid CH, Chan J. Hospital ownership and quality of care: what explains the different results in the literature? Health Econ 2008:17:1345-62.

37 Tiemann O, Schreyögg J, Busse R, Hospital ownership and efficiency: a review of studies with particular focus on Germany. Health Policy 2012;104:163-71.

38 Kondilis E, Gavana M, Giannakopoulos S, Smyrnakis E, Dombros N, Benos A. Payments and quality of care in private for-profit and public hospitals in Greece. BMC Health Serv Res 2011;11:234.

39 Quercioli C, Messina G, Basu S, McKee M, Nante N, Stuckler D. The effect of healthcare delivery privatisation on avoidable mortality: longitudinal cross-regional results from Italy, 1993-2003. J Epidemiol Community Health 2013;67:132-8.

40 McKee M, Edwards N, Atun R. Public-private partnerships for hospitals. Bull World Health Organ 2006;84:890-6.

41 Navarro V. The mistake of austerity policies, including cuts, in the national health system. Gac Sanit 2012;26:174-5.

42 Vega MA. Menos fraude, menos recortes. El Pais, 23 January 2013.
43 Spanish Ministry of Health, Gasto Sanitario Publico (public health care expenditure), www. msc.es/organizacion/sns/docs/gasto08.pdf.

44 McKee M, Karanikolos M, Belcher P, Stuckler D. Austerity: a failed experiment on the people of Europe. Clin Med 2012;12:346-50.

45 International Monetary Fund. World economic outlook, October 2012. Coping with high debt and sluggish growth. 2012. www.imf.org/external/pubs/ft/weo/2012/02/pdf/text.pdf.

46 Klein, N. The shock doctrine: the rise of disaster capitalism. Penguin Group, 2007.

47 Kentikelenis A, Karanikolos M, Papanicolas I, Basu S, McKee M, Stuckler D. Health effects of financial crisis: omens of a Greek tragedy. Lancet 2011;378:1457-8.

48 Garcia-Rada, A. Wages are slashed and waiting lists grow as Catalonia's health cuts bite. BMJ 2011;343:d6466

49 Metges de Catalunya. El pressupost de Salut confirma les advertències de Metges de Catalunya (The health care budget confirms the warnings of Catalan Doctors Association). 2012. metgesblog.com/2012/01/30/el-pressupost-de-salut-confirma-les-advertencies-demetges-de-catalunya.

50 Federación de Asociaciones para la Defensa de la Sanidad Pública. Informe sobre los recortes sanitarios en las Comunidades Autónomas (Report of the health care cuts in the Spanish Autonomous Communitites). 2012.

51 Eldebat cat. Nova reducció brutal del Pressupost de Salut pel 2013 (New brutal cuts to the Catalan health care budget of 2013). April 15 2012. www.eldebat.cat/cat/viewer.php? IDN=102650.

52 La Vanguardia, CiU y PSC imponen vetos en la comisión parlamentaria de Sanidad (CiU and PSC impose vetoes on the parliamentary committee on Health). La Vanguardia, 30 April 2013.

53 Sevillano, E. Paralizar el plan sanitario sería la primera medida de ahorro (To stop the health care reforms would be the first measure of cost containment). El Pais, 12 December 2012.

Accepted: 15 March 2013

Cite this as: BMJ 2013;346:f2363

(c) BMJ Publishing Group Ltd 2013 